\title{
Internationalization of Entrepreneurial Ventures in Transition Countries
}

\author{
Article history: \\ Received: 5 June 2017 \\ Sent for revision: 1 July 2017 \\ Received in revised form: 8 November 2017 \\ Accepted: 8 November 2017 \\ Available online: 25 December 2017
}

\begin{abstract}
Healthy and flexible economic structure of entrepreneurial ventures and small enterprises is treated as an indispensable part of the economic mosaic and significant element of international competitiveness. The above mentioned aspect of entrepreneurial ventures will be analyzed through the degree of involvement in the process of internationalization in the context of regional and global integration processes as the last stage of the economic aspects of the globalization process by observing the level achieved in the context of transition countries in comparison with other groups. The main objective of the work is focused on the analysis of the involvement of the entrepreneur in the process of internationalization of operations depending on the stage of economic development of the group of countries and the stage reached in the development of the entrepreneurial process. Thus, the available data of the GEM project allow the analysis and identification of a potential specific group of transition countries compared to other countries with different development levels in terms of the achieved level of involvement in the process of internationalization of entrepreneurial ventures, by using the application of statistical methods for determining differences between groups using MANOVA, Anova, discriminant analysis and Mahalanobis distance. The results of research will directly set goals in terms of the degree of involvement of the entrepreneur in the process of internationalization of operations depending on the achieved level of economic development and the stages in the development of the entrepreneurial process, singling out specific countries in transition.
\end{abstract}

Keywords: small business, entrepreneurial venture, internationalisation, transition

\footnotetext{
${ }^{1}$ University of Novi Sad, Faculty of Economics Subotica

${ }^{2}$ University of Novi Sad, Faculty of Economics Subotica, marics@ef.uns.ac.rs 
Leković B., Marić S.: Internationalization of Entrepreneurial Ventures in Transition...

\title{
Internacionalizacija preduzetničkih poduhvata u tranzicionim zemljama
}

\begin{abstract}
Apstrakt: Zdrava i fleksibilna ekonomska struktura preduzetničkih poduhvata i malih preduzeća tretiraju se kao neophodni delovi ekonomskog mozaika $i$ važnih elemenata međunarodne konkurentnosti. U skladu sa pomenutim aspektom, preduzetničkih poduhvati biće analizirani kroz stepen uključenosti u procesu internacionalizacije u kontekstu regionalnih i globalnih integracionih procesa, kao poslednjoj fazi ekonomskog aspekta procesa globalizacije posmatrajući nivo postignut u kontekstu zemalja u tranziciji u poređenju sa drugim odabranim grupama. Glavni cilj rada je fokusiran na analizu uključivanja preduzetnika u proces internacionalizacije poslovanja u zavisnosti od faze ekonomskog razvoja grupe zemalja $i$ od stepena u razvoju preduzetničkog procesa. Analiza dostupnih podataka GEM projekta omogućavaju analizu i identifikovanje potencijalnih specifičnosti grupe tranzicionih zemalja u poređenju sa ostalim definisanim podgrupama u uzorku različitog stepena razvijenosti sa aspekta ostvarenog nivoa uključenosti u process internacionalizacije preduzetničkih poduhvata primenom statističkih postupaka za utvrđivanje razlika između grupa uzorka primenom MANOVA, Anova, discriminant analysis and Mahalanobis distance. Rezultati istraživanja su direktno udovoljili zahtevima postavljenih ciljeva u pogledu stepena uključenosti preduzetnika $u$ proces internacionalizacije poslovanja u zavisnosti od dostignutog stepena ekonomskog razvoja $i$ faze u razvoju preduzetničkog procesa, čime se izdvajaju posebno zemlje u tranziciji.
\end{abstract}

Ključne reči: mala preduzeća, preduzetnički poduhvati, internacionalizacija poslovanja, tranzicija

\section{Introduction}

Do larger markets favour larger businesses? Will new or small businesses have their role in a certain global economy? If we guide ourselves with experiences from the past, the answer would be yes, large markets favour larger business, and no, the role of small businesses will be limited in the future global economy. Undoubtedly, many of the studies written so far in this area highlight entrepreneurship and entrepreneurial sector as the most efficient instrument for transformation of former socialist countries from centralised and planned towards market-oriented economies (Smallbone \& Welter, 2001).

As it could be seen from the above mentioned opinion, entrepreneurship as a type of activity plays the same role in all economies regardless of the degree of development, but also, the quality of entrepreneurial activities in the form of contribution to economic growth and development differs depending on the 
Leković B., Marić S.: Internationalization of Entrepreneurial Ventures in Transition...

level of development of the country where the quality of environment is one of the key criteria of distinguishing, but also a direct factor of development of entrepreneurship.

Changes widening economic markets can be considered as two types of changes (Reynolds, 1997):

1. technological advances in communication and sports;

2. harmonization of the regulatory environment in which economic activity is taking place.

All of these phenomena are viewed as the advantage of the global market, especially for large businesses, diminishing or even questioning the role and possibilities of small businesses. Based on what we have said above, we pose the question as to what are the opportunities for small businesses on the global market. Its significance, originality, or contribution to new knowledge in the field, should be clearly and concisely stated. The central research aim and the key problem orientation is related to and focused on the analysis of the involvement of the entrepreneurial ventures in the process of internationalization depending on the stage of economic development of the group of countries and the stage reached in the development of the entrepreneurial process based on selected variables in comparison to other groups of countries defined by methodology of Word Economic Forum. The research methodology involves the use of parametric procedures due to the characteristics of the selected variables and the number of observations in the sample. Multivariate procedures MANOVA and discriminant analysis will be used. From univariate procedures, ANOVA will be applied. The application of the chosen methodology is aimed to determine the characteristics of each subsample (group of countries), potential differences, boundaries, distance and homogeneity in order to make appropriate conclusions. The novelty of this study is segregation of the group of transition countries, as a stage in the development, in comparison with other groups of countries in the form of the existence of differences for observed variables.

\section{Theoretical Background - basic attitudes}

\subsection{Entrepreneurship and Small Business Ventures in Transitional Countries}

The development potential of small businesses and entrepreneurial ventures represents a significant source of competitive advantage of highly developed countries. The competitive contribution of this segment of economy is reflected in the high economic value based on innovativeness. In countries with transition experience, the significance of entrepreneurial sector is not 
Leković B., Marić S.: Internationalization of Entrepreneurial Ventures in Transition...

diminished. In transition countries, the entrepreneurial sector is not only responsible for the development of innovative capacities, and especially, due to transition recession that comes to the front is its significant role in the form of new employment (Johnson and Loveman, 1995). The process of economic transformation, that is, liberalization and privatization that took place in former centralized planned economies has resulted in enhancement of international competitiveness based on the growth of enterprise whose source were the consequence of including these markets into global framework, primarily based on the basis of the process of business internationalization (Meyer, 2001; Jansson, 2007a). Thus, the capacities of the entrepreneurial sectors are a vital component of the very process of transformation and building new economic structure. In most cases, the entrepreneurial sector of transition countries, taking into account all specific features, is not necessarily different in comparison with developed market economies. In this sense, it can be concluded that the nature of the environment is identical, whereas the intensity of relationships is different, which is absolutely the consequence of the degree of development of national economy and business stability of an environment. In other words, all barriers that are present and affect the entrepreneurial sector of developed countries are also present in transition countries, but for the above mentioned reason, in the latter case, they are at a far higher level.

Numerous studies conducted on the topic of entrepreneurship have contributed to grouping of barriers in the following several categories. The most significant group of barriers are referred to as formal obstacles reflected in the high tax obligations and unfavourable general regulatory environment (Bartlett and Bukvič, 2001; Hashi, 2001). The following category mentioned is named informal barriers, including implementation of law, corruption and unfair competition of a large section of shadow economy (Muent et al., 2001). Another group of significant barriers to the functioning of small business are the barriers of environment, in the form of lack of funds and low purchasing power (Pissarides et al., 2000). It is necessary to point to the group of barriers related to the lack of business skill due to lack of business experience in transition countries (Roberts and Tholen, 1998). Thus classified barriers found on the path to development of small businesses and entrepreneurial ventures at the same time represent a factor of international competitiveness and affect the degree of inclusion into the process of internationalization of business. Thus we can say, in the context of the above claims, the strength or development of the entrepreneurial sector is reversely proportionate to the significance of the listed barriers.

In the circumstances characteristic of transition economies, there is a very weak entrepreneurial sector, where the barriers of any kind represent a significant limitation in the development of both individual entrepreneurial ventures and the sector as a whole. These limitations aggravate the 
Leković B., Marić S.: Internationalization of Entrepreneurial Ventures in Transition...

development path of entrepreneurship in all the phases of entrepreneurial process from initiating an entrepreneurial venture to more mature phases of business reflected in the form of internationalization, development of new products and application of new technology. Thus, in the economic environment of transitional countries, taking into account all the listed specific features, government and its institution have a key role in the formation and regulation of entrepreneurial environment. Governments are responsible for the creation and implementation of the institutional context that predominantly enables or limits the development of entrepreneurship. According to Zubović and Hanić (2009) as a direct consequence of improved quality of financial institutions activities, there have been completely new financial instruments introduced on the Serbian market, which include financial leasing and private pension funds. Positive investments environment attracted new foreign investments both on greenfield investments and mergers \& acquisitions side of the remaining state owned companies. Nowadays, after a considerable time period that has passed since the beginning of economic transformation, the countries of Central and Eastern Europe and former Soviet republics can be divided into two categories: countries where the process of market reforms has been realized at a high level, and countries where the economic reform process was partially or unsuccessfully realized (Smallbone et al., 2010).

As regards endeavours towards overcoming the above mentioned barriers and encouraging the development of the entrepreneurial sector, the transition environment exhibits significant specific features and differences in comparison with the usual economic environment of mature market economies, in the form of close connection between entrepreneurial behaviour and business environment (Manolova et al., 2008; Peng, 2003). This refers to the government policies and activities as the key elements of external environment for the development of entrepreneurship. Thus institutions feature as limiting and stimulating forces for the development of entrepreneurship by creating positive or negative perception of entrepreneurial possibilities whether at collective or individual level. So, changes of technological nature, political relations, legal framework and macroeconomic elements, but also the development of social trends can be a basis for the existence or emergence of new business opportunities (Shane, 2003). These and similar changes are especially present in the case of transition countries, where the entrepreneurial environment has undergone fundamental changes with the beginning of reform processes and transition from centralized planned to market based system of business operations. In the transition process, the government is the key actor of institutional changes and creator of business environment, i.e. entrepreneurial opportunities, because instability and uncertainty of the business environment can limit the development of entrepreneurship, as it affects the high level of uncertainty in the perception of potential entrepreneurs. 
Leković B., Marić S.: Internationalization of Entrepreneurial Ventures in Transition...

Successful business operations in the changing environment can be hoped for only by flexible businesses, both in terms of organizational structure and of business policies, management system etc. On the path to attaining their objectives, businesses encounter a whole range of limitations, including decline of market needs, intensity of competition, legal limitations, inadequate economic policies of the country and many others. One of the most significant limitations is the existing markets, which can be in stagnation or decline, for the following reasons:

1. Increasingly advanced technology is able to produce an increasing amount of products;

2. The national income rate on the existing market is declining, resulting in the declining purchasing power of consumers.

It is these reasons that tell us that the existing (national) markets are becoming too narrow and insufficient, so that businesses are forced to search for new ones. Thus, lately, there are more and more factors directing businesses to foreign market and expansion of operations outside national borders, that is, the processes of internationalization and globalization of business are becoming inevitable. The global market implies equal conditions of operation for all participants, offers great opportunities for development, especially when it comes to increasing the capacity o sale, providing new market resources and improving the competitive advantage. The process of business internationalization itself starts from closer and more secure markets and simpler forms of entry, towards further, riskier markets and more complex forms of entry.

In most cases, the first entry to the international market is achieved by export, as the simplest form of internationalization characterized by minimum investment and low degree of risk. The current issue of entry to international market is much more complex. For this reason the globalization process requires a strategic approach, which means that entry to a foreign market cannot be random, without thinking, for we can say in advance for these attempts of entry that they will result in failure. Entry to a foreign market requires a planned approach, which means that every step to be made to this end must previously be well considered. Businesses thinking of joining the international market must recognize the opportunities, way of realizing competitive advantages, assess their own possibilities, all with the aim of minimizing the potential risk of entering a foreign market.

One of the strategies of small business in relation to global competition is avoidance. One of predominant opinions as regards the business strategy of small business is that small businesses should avoid competition with giants, for which there are several ways (Agmon, 1994):

- focussing on certain activities; 
Leković B., Marić S.: Internationalization of Entrepreneurial Ventures in Transition...

- focussing on certain market segments that are not the target of large businesses;

- taking on risks based on specific managerial attributes;

- using the advantage of flexibility and adaptation to changes in the environment;

- cooperation relationships with large businesses;

- permanent innovation aimed at becoming large.

\subsection{Internationalization Activities of Entrepreneurial Ventures: Comparation of Tranzitional Countries with Others}

Conventional winsdom would suggest that firms usually internationalize after a period of a domestic maturity (Oviatt et al, 1995). Young and new technology-based companies typically face growth challenges characterized by intense product and/or process innovations-frequently combined with business model innovations-and early and fast internationalization processes (Jonees et al., 1999, Prece, 1999). The revolution in transport and transfer of information in mid $19^{\text {th }}$ century marked the beginning of multinational competition. Revolution in information and communication created global comparison as we know it today. The reason for internationalization (globalization) is often sought in the reduction of fixed costs. According to Axinn and Matthyssens (2002), the development of almost unlimited global economy is based on the growth of low cost technology, reduction of trade barriers and opening of the previously closed markets. Given that survival and progress on the global market requires infrastructure, adequate marketing endeavour on the market, many deem that this is an opportunity for large businesses and neglect the role and position of small enterprises. Contrary to this, there are small businesses that are not protected by special measures of government policy, but are also present on the global market.

Market expansion and globalization did not go in parallel with the growth of the role of large businesses as it was expected. The latest data on small businesses show a substantial and expansive role of this type of businesses in the global economy as well, which is different across sectors depending on the ways of providing competitive advantage. As owners/entrepreneurs/managers are present in every business activities of small business, carrying out researches at this level means also consideration of attitudes, aspirations and activities of the owner himself (Leković and Marić, 2015). In accordance with it, it is necessary to determine how owners/entrepreneurs/managers of small businesses experience success and how their perception of success exerts influence on the enterprise performance.The growing globalization creates a new and more dynamic business environment, whereas the process of business internationalization is 
Leković B., Marić S.: Internationalization of Entrepreneurial Ventures in Transition...

not intended only for the large ones, the participants to a high extent are small business as well (Gjellerup, 2000). What is of great importance for global economy is the process of liberalization and privatization that took place in former centralized planned economies, which enhanced international competitiveness due to growth of businesses as a result of inclusion of these markets into global framework (Meyer, 2001; Jansson, 2007a).

Numerous researchers highlight the growing importance of former closed markets within the global economy as the main reason for change in the existing mosaic of business internationalization (Axinn and Matthyssens, 2002; Ruzzier et al., 2006). A number of authors advocate this viewpoint, with the exception of Jansson (2007b), who views the opening of growing markets over the past decade as the main driver of the above mentioned third wave of business internationalization (Soderman et al., 2008). The first wave of internationalization was initiated by the industrialization of Western countries. The second wave of internationalization was initiated after World War II with the expansion of international corporations from East Asia. Crucial events for the process of internationalization of business are related to the liberalization and reforms of centralized planned economies within the third wave of internationalization, where a significant role and participation was taken by small businesses, far more than until now, equally from growing and mature markets. One of possible reasons for these processes is that business opportunities contribute to high economic growth within new markets, with a reduced risk and removed barrier on the global market. What is very important, the above mentioned markets enable entry to foreign markets in already known, traditional ways (Child and Rodrigues, 2005; Meyer and Gelbuda, 2006; Salmi, 2000). The significance of growing markets is reflected in the opinion of Peng and Meyer (2011), where their share in the world amounts to about $84 \%$ of global population, $26 \%$ of the world's GDP and, very importantly, growing markets in general have a very high economic growth rate. Likewise, growing markets are a magnet for investment, providing great growth opportunity in the future period (Cavusgill et al., 2002). However, barriers still exist (Meyer, 2001), in the sense of drastic difference in the market context in comparison with mature markets (Ghauri and Holstius, 1996).

The general trend that has encouraged international activities of small businesses is related to the globalization process, which had a far greater impact on small businesses compared to large ones, regardless of their significant international experience (UNCTAD, 2011; Gjellerup, 2000). The share of small businesses in export to EU-27 in 2009 was 25\% (European Commission, 2010b). In East Asia, export was contributed by small businesses by more than 30\% in 2002 (Harvie and Lee, 2005). 
Leković B., Marić S.: Internationalization of Entrepreneurial Ventures in Transition...

Based on the above presented information, we can say that there is solid evidence that small businesses are direct participants in international business operations, with a tendency of growth. Small businesses have recognized the influence and challenge of globalization process and new business environment, far better than large businesses, although the latter have international experience (Cabusgil et al., 2002; Eriksson et al., 2000; Gjellerup, 2000; Meyer and Gelbuda, 2006).

\section{Methodology}

\subsection{Data and variables}

The main source of data analyzed factors (variables) activities of the entrepreneurial process in this paper are the results of research on the GEM project in 2014. According to a feature of the criterion of GDP per capita in US $\$$ and methodologists WEF there are three different stages of economic development as well as three groups of countries: "factor driven economies" for countries with GDP up to 3000 \$ per capita, "efficiency driven economies" - for countries with a GDP up to $\$ 17,000$ per capita and "innovation driven economies" - for countries with GDP more than 17,000 \$ per capita. Under the group within the second group of countries called efficiency driven economies was formed with the authors titled efficiency transitional driven economies consisting of seven transition countries mainly in Central and Eastern Europe plus China in order to perform the analysis according to the selected bookmark in relation to other groups. The source of information for the variable GDP per capita in US \$ is International Monetary Fund, World Economic Outlook Database, October 2010.

The level of economic development is represented by GDP per capita in US \$ (GDP per Capita in US \$ on PPP Basis), which is also the basis for the classification of countries by stages of economic development. The following variables were used in the paper>

Variable marked suboan (Nascent entrepreneur involved in setting up a business) refers to entrepreneurial activity in the phase of the entrepreneurial process in which entrepreneurs emerge as individuals who are currently owners or managers of new businesses who have engaged resources and achieve a certain type of revenue less than three month.

Variable babyb (Owner-manager of young business - up to 3.5 years old) represents individuals' bearers of entrepreneurial activity in the form of the owner or manager of the business from a certain type of revenue in less than 3.5 years 
Leković B., Marić S.: Internationalization of Entrepreneurial Ventures in Transition...

Variable marked TEA (Total Early-Stage Entrepreneurial Activity) index is the main indicator of the volume of entrepreneurial activity in this study and contains the previous two indicators.

Variable estabbu (Owner - manager of an established business more than 3.5 years old) is an indicator of entrepreneurial activity in last phase of the entrepreneurial process, includes individuals who fit the owner or entrepreneur and realize a certain income more than 3.5 years of operation.

Variable anybus (Overall Entrepreneurial Activity), which involves entrepreneurial activity from the previous three phases.

The scope of variables of business internationalization in all phases of the entrepreneurial process is delimited as follows: entrepreneurial ventures without business internationalization, entrepreneurial ventures with up to $25 \%$ of business internationalization, entrepreneurial ventures of $25-70 \%$ of business internationalization and entrepreneurial ventures with the internationalization of business more than $75 \%$.

\subsection{Hypothesis and methodology}

As already presented in the introductory remarks, the key problem, as well as the entire problem orientation of this research is related to the analysis of the scope and structure of entrepreneurial activities and their involvement in the process of internationalization of the business, and the potential association with the degree of economic development of countries in transition (mainly Central and Eastern Europe), as well as the specific economic conditions in relation to a selected group of countries smaller and greater development.

Central research intention is related to the determination of the degree of interdependence of economic growth, the volume of business internationalization and phase of the entrepreneurial process. Available data of selected characteristics enable it to undertake an analysis in the form of determining the difference between groups with different level of development of the country, in all phases of the entrepreneurial process, as well as the interconnections and relationships observed phenomena degree of economic development, the process of internationalization of operations and phases of the entrepreneurial process.

Selected characteristics, i.e. variables have the parametric space exploration properties and are therefore analyzed by parametric methods. This paper will show the descriptive parameters, mean, standard deviation (SD), minimum and maximum of the value of the coefficient of variation (Cv) confidence interval, a measure of the asymmetry skewness, extent and value of skewness and kurtosis of the Kolmogorov-Smirnov test. MANOVA multivariate methods will be used. From univariate procedures, ANOVA will 
Leković B., Marić S.: Internationalization of Entrepreneurial Ventures in Transition...

be applied. Application of procedures on the basis of which it receives a rate adds a new dimension to this study. By calculating the coefficient of discrimination aside, the characteristics that determine the specificity of the subsamples and characteristics that need to be excluded from further processing, which is performed by reduction of the observed area. Also see the assessment of the homogeneity of subsamples; the distance between them is intended to be as close as possible to better learn the observed phenomena.

The purpose of the application of mathematical and statistical analysis aims to determine the characteristics of each subsample, the homogeneity and the distance between them in relation to derivative features that would be able to draw conclusions with a certain degree of reliability.

Methods of proving the existence of similarities or differences between subsamples confirm the hypothesis about the similarity or reject it (the alternative hypothesis is confirmed), which that indicate the existence of differences. In testing the hypotheses used to the critical value of $p$, which poses a risk deduction. If $p>0.100$, there is no reason not to accept the initial hypothesis. To reject the initial hypothesis we will use two thresholds of significance. In the event that is $0.10>P>0.05$ accepts the alternative hypothesis of an increased risk of concluding, when $p<0.05$ accepts the alternative hypothesis and shows that there are substantial (significant) differences.

In the final analysis of the data obtained, with equal care will be discussed any other issues which were subsequently found to be of significance for a fuller illumination of the problem that is being investigated.

In accordance with the objectives of the research within a defined research area and observed phenomena, data and methodology selected, we set the following research assumptions:

MANOVA procedure to test the hypothesis $\mathrm{H} 1$, which reads as follows:

H1: There are significant differences between some subsamples, defined groups of countries for the observed thematic unity and depending on the volume of business internationalization of total entrepreneurial activity.

Method of discriminant analysis to test the hypothesis $\mathrm{H} 2$ :

H2: There are a clearly defined boundaries between some subsamples defined groups of countries for the observed thematic unity and depending on the volume of business internationalization of total entrepreneurial activity.

ANOVA procedure $\mathrm{H} 3$ : 
Leković B., Marić S.: Internationalization of Entrepreneurial Ventures in Transition...

H3: There is a significant difference between some subsamples according to individual characteristics of the total volume of business internationalization of entrepreneurial activity.

\section{Results Analysis and Discussion}

The central focus of this research is focused on determining the specificity particularly the groups of countries in transition, as defined by the criteria of the author. The main intention is reflected in the establishment of important differences and specific demarcation in relation to other groups of countries, posted on the basis of internationally recognized methodologies. Achievement of this objective is attained and the scientific contribution of this paper in the form of interpretation, analysis and presentation of the observed phenomena, and the volume of business internationalization of total entrepreneurial activity of transition countries of the mentioned geographical area. In this way, the observed group of countries deserves special characteristics of the research area in terms of the observed phenomena.

As open questions should be the subject of the sabsequent analysis, it is necessary to test hypotheses and establish the existence of differences, their significance and limits as illustrated in Table 1. Differences between the groups of countries and clearly defined limits are done by MANOVA procedures. Based on the value $p=.000$ (MANOVA analysis) and $p=.000$ (discriminative analysis), hypothesis $\mathrm{H}_{1}$ and hypothesis $\mathrm{H}_{2}$ are accepted. It means that there is a difference and clearly defined limit between the groups of countries.

\section{Table 1}

MANOVA and discriminative analysis between groups of countries relating to observed characteristics

\begin{tabular}{rrrr}
\hline Analysis & $n$ & $F$ & $p$ \\
\hline MANOVA & 4 & 7,599 & .000 \\
discriminative & 4 & 16979, & .000 \\
\hline
\end{tabular}

Source: Autors' Calculation

Anova analysis tested the third hypothesis but also a statistically significant difference between the groups of countries according to the presented. We identified a statistically significant difference between the groups of countries defined by different degrees economic development according to the percentage entrepreneurial ventures without a business internationalization (\% within ANY: No customers outside country) at the level F $(3,26564.410)=$ 
Leković B., Marić S.: Internationalization of Entrepreneurial Ventures in Transition...

6.343, $p=.001$. A subsequent comparison of using the Tukey HSD test, significant difference between mean values only was found in the first and third groups, and the first and fourth groups of countries, i.e. a significantly higher percentage of total entrepreneurial activity without internationalization of operations is present in factor-driven countries.

In other variables, we identified a statistically significant difference between the groups of countries defined by different degrees of development according to the percentage of business internationalization of the total entrepreneurial activities (\% within ANY: Export: $1-25 \%$ of customers outside country) at the level $F(3,12706,544)=6.573, p=.001$. A subsequent comparison of using the Tukey HSD test, significant difference between mean values was found only in the first and third groups of countries, i.e. a significantly higher percentage of total entrepreneurial activity with business internationalization is present in innovation-driven countries.

Table 2

ANOVA analysis for observed characteristics/variables

\begin{tabular}{|c|c|c|c|c|c|c|}
\hline & & $\begin{array}{l}\text { Sum of } \\
\text { Squares }\end{array}$ & $d f$ & $\begin{array}{l}\text { Mean } \\
\text { Square }\end{array}$ & $F$ & Sig. \\
\hline \multirow{3}{*}{$\begin{array}{lr}\% \text { within } & \text { ANY: No } \\
\text { customers } & \text { outside } \\
\text { country } & \end{array}$} & Between Groups & 8023,357 & 3 & 2674,452 & \multirow[t]{3}{*}{6,343} & \multirow[t]{3}{*}{, 001} \\
\hline & Within Groups & 26564,410 & 63 & 421,657 & & \\
\hline & Total & 34587,767 & 66 & & & \\
\hline \multirow{3}{*}{$\begin{array}{l}\text { \% within ANY: Export: } \\
1-25 \% \text { of customers } \\
\text { outside country }\end{array}$} & Between Groups & 3977,377 & 3 & 1325,792 & \multirow[t]{3}{*}{6,573} & \multirow[t]{3}{*}{, 001} \\
\hline & Within Groups & 12706,544 & 63 & 201,691 & & \\
\hline & Total & 16683,921 & 66 & & & \\
\hline \multirow{3}{*}{$\begin{array}{l}\% \text { within ANY: Export: } \\
25-75 \% \text { of customers } \\
\text { outside country }\end{array}$} & Between Groups & 398,703 & 3 & 132,901 & \multirow[t]{3}{*}{3,855} & \multirow[t]{3}{*}{,013 } \\
\hline & Within Groups & 2172,124 & 63 & 34,478 & & \\
\hline & Total & 2570,828 & 66 & & & \\
\hline \multirow{3}{*}{$\begin{array}{l}\% \text { within ANY: Export: } \\
75-100 \% \text { of customers } \\
\text { outside country }\end{array}$} & Between Groups & 148,360 & 3 & 49,453 & \multirow[t]{3}{*}{2,126} & \multirow[t]{3}{*}{, 106 } \\
\hline & Within Groups & 1465,780 & 63 & 23,266 & & \\
\hline & Total & 1614,140 & 66 & & & \\
\hline
\end{tabular}

Source: Autors' Calculation

The following variables, identified a statistically significant difference between the groups of countries defined by different degrees of development according to the percentage of business internationalization of the total entrepreneurial activities (\% within ANY: Export: $25-75 \%$ of customers outside country) at the level $F(3,2172,124)=3,855, p=.013$. A subsequent comparison of using the Tukey HSD test, significant difference between mean values was found only between the second and forth groups of countries, i.e. a significantly higher percentage of total entrepreneurial activity with business internationalization at this level, exceptional in efficiency driven (transition countries). 
Leković B., Marić S.: Internationalization of Entrepreneurial Ventures in Transition...

In the last variable that represents the highest level of internationalization of business (\% within MISSING: Export: $25-75 \%$ of customers outside country), there is no statistically significant difference between the groups of countries.

\section{Table 3}

Multiple Comparisons for observed characteristics/variables

\begin{tabular}{|c|c|c|c|c|c|c|c|}
\hline \multirow[t]{2}{*}{$\begin{array}{l}\text { Dependent } \\
\text { Variable }\end{array}$} & \multirow{2}{*}{$\begin{array}{lr}\text { (I) } & \text { COUNTRY } \\
\text { GROUP } & \text { GCR } \\
\text { REPORT } & \text { 2012- } \\
2013-4 \text { CAT } & \end{array}$} & \multirow[t]{2}{*}{$\begin{array}{ll}\text { (J) } & \text { COUNTRY } \\
\text { GCR ROUPP } \\
\text { 2013 - } 4 \text { CAT }\end{array}$} & \multirow[t]{2}{*}{$\begin{array}{c}\text { Mean } \\
\text { Difference } \\
(I-J)\end{array}$} & \multirow[t]{2}{*}{$\begin{array}{l}\text { Std. } \\
\text { Error }\end{array}$} & \multirow[t]{2}{*}{ Sig. } & \multicolumn{2}{|c|}{$\begin{array}{c}95 \% \\
\text { Confidence } \\
\text { Interval }\end{array}$} \\
\hline & & & & & & $\begin{array}{l}\text { Lowe } \\
r \\
\text { Boun } \\
d \\
\end{array}$ & $\begin{array}{l}\text { Upper } \\
\text { Bound }\end{array}$ \\
\hline \multirow{12}{*}{$\begin{array}{l}\% \text { within ANY: } \\
\text { No customers } \\
\text { outside country }\end{array}$} & \multirow{3}{*}{ 1: factor } & Stage 2: efficiency driven & 2,17840 & 7,125 & ,990 & 16,62 & 20,98 \\
\hline & & $\begin{array}{lll}\text { Stage } & 3: & \text { innovation } \\
\text { driven } & & \end{array}$ & $21,77731^{*}$ & 7,183 & ,018 & 2,82 & 40,73 \\
\hline & & $\begin{array}{l}\text { Stage 4: efficiency driven } \\
\text { (transition countries) }\end{array}$ & $26,34043^{*}$ & 8,904 & ,022 & 2,84 & 49,83 \\
\hline & \multirow{3}{*}{$\begin{array}{l}\text { Stage 2: efficiency } \\
\text { driven }\end{array}$} & Stage 1: factor driven & $-2,17840$ & 7,125 & 990 & 20,98 & 16,62 \\
\hline & & $\begin{array}{lll}\text { Stage } & 3: & \text { innovation } \\
\text { driven } & & \end{array}$ & $19,59891^{*}$ & 6,123 & 011 & 3,43 & 35,75 \\
\hline & & $\begin{array}{l}\text { Stage 4: efficiency driven } \\
\text { (transition countries) }\end{array}$ & $24,16203^{*}$ & 8,073 & ,020 & 2,85 & 45,46 \\
\hline & \multirow{3}{*}{$\begin{array}{l}\text { Stage 3: innovation } \\
\text { driven }\end{array}$} & Stage 1: factor driven & $-21,77731^{*}$ & 7,183 &, 018 & 40,73 & $-2,82$ \\
\hline & & Stage 2: efficiency driven & $-19,59891^{*}$ & 6,123 & ,011 & 35,75 & $-3,43$ \\
\hline & & $\begin{array}{l}\text { Stage 4: efficiency driven } \\
\text { (transition countries) }\end{array}$ & 4,56312 & 8,125 & 943 & 16,87 & 26,00 \\
\hline & \multirow{3}{*}{$\begin{array}{l}\text { Stage 4: efficiency } \\
\text { driven (transition } \\
\text { countries) }\end{array}$} & Stage 1: factor driven & $-26,34043^{*}$ & 8,904 & 022 & 49,83 & $-2,84$ \\
\hline & & Stage 2: efficiency driven & $-24,16203^{*}$ & 8,073 & ,020 & 45,46 & $-2,85$ \\
\hline & & $\begin{array}{lll}\text { Stage } & 3: & \text { innovation } \\
\text { driven } & & \\
\end{array}$ & $-4,56312$ & 8,125 & 943 & 26,00 & 16,87 \\
\hline \multirow{7}{*}{$\begin{array}{l}\% \text { within ANY: } \\
\text { Export: } 1-25 \% \\
\text { of customers } \\
\text { outside country }\end{array}$} & \multirow{3}{*}{$\begin{array}{l}\text { Stage } \\
\text { driven }\end{array}$} & Stage 2: efficiency driven & $-3,05420$ & 4,927 & ,925 & 16.05 & 9,95 \\
\hline & & $\begin{array}{l}\text { Stage } \\
\text { driven }\end{array}$ & $-17,82395^{*}$ & 4,968 & ,004 & 30,93 & $-4,71$ \\
\hline & & $\begin{array}{l}\text { Stage 4: efficiency driven } \\
\text { (transition countries) }\end{array}$ & $-15,65252$ & 6,158 & ,063 & 31,90 & ,59 \\
\hline & \multirow{3}{*}{$\begin{array}{l}\text { Stage 2: efficiency } \\
\text { driven }\end{array}$} & Stage 1: factor driven & 3,05420 & 4,927 & 925 & $-9,95$ & 16,05 \\
\hline & & $\begin{array}{l}\text { Stage } \\
\text { driven }\end{array}$ & $-14,76975$ & 4,235 & ,005 & 25,94 & $-3,59$ \\
\hline & & $\begin{array}{l}\text { Stage 4: efficiency driven } \\
\text { (transition countries) }\end{array}$ & 9832 & 5,583 & 120 & 27,33 & 2,13 \\
\hline & $\begin{array}{l}\text { Stage 3: innovation } \\
\text { driven }\end{array}$ & $\begin{array}{l}\text { Stage 1: factor driven } \\
\text { Stage 2: efficiency driven }\end{array}$ & $\begin{array}{l}17,82395^{*} \\
14,76975^{*}\end{array}$ & $\begin{array}{l}4,968 \\
4,235\end{array}$ & $\begin{array}{l}, 004 \\
, 005\end{array}$ & $\begin{array}{l}4,71 \\
3,59\end{array}$ & $\begin{array}{l}30,93 \\
25,94\end{array}$ \\
\hline
\end{tabular}


Leković B., Marić S.: Internationalization of Entrepreneurial Ventures in Transition...

\begin{tabular}{|c|c|c|c|c|c|c|c|}
\hline & & $\begin{array}{l}\text { Stage 4: efficiency driven } \\
\text { (transition countries) }\end{array}$ & 2,17143 & 5,619 & ,980 & 12,65 & 17,00 \\
\hline & & Stage 1: factor driven & 15,65252 & 6,158 & ,063 &,- 59 & 31,90 \\
\hline & $\begin{array}{l}\text { Stage 4: efticlency } \\
\text { driven }\end{array}$ & Stage 2: efficiency driven & 12,59832 & 5,583 & ,120 & $-2,13$ & 27,33 \\
\hline & countries) & $\begin{array}{l}\text { Stage 3: innovation } \\
\text { driven }\end{array}$ & $-2,17143$ & 5,619 & ,980 & 17,0 & 12,65 \\
\hline & & Stage 2: efficiency driven & 1,07568 & 2,037 & ,952 & $-4,30$ & 6,45 \\
\hline & Stage 1: factor & $\begin{array}{l}\text { Stage } 3: \quad \text { innovation } \\
\text { driven }\end{array}$ & $-1,50522$ & 2,054 & ,884 & $-6,92$ & 3,91 \\
\hline & & $\begin{array}{l}\text { Stage 4: efficiency driven } \\
\text { (transition countries) }\end{array}$ & $-6,58769$ & 2,546 & ,057 & $13,30^{-}$ & ,13 \\
\hline & & Stage 1: factor driven & $-1,07568$ & 2,037 & ,952 & $-6,45$ & 4,30 \\
\hline$\%$ within ANY: & Stage 2: efficiency & $\begin{array}{l}\text { Stage 3: innovation } \\
\text { driven }\end{array}$ & $-2,58090$ & 1,751 & ,459 & $-7,20$ & 2,04 \\
\hline $\begin{array}{l}\text { Export: } 25-75 \% \\
\text { of customers }\end{array}$ & & $\begin{array}{l}\text { Stage 4: efficiency driven } \\
\text { (transition countries) }\end{array}$ & $-7,66337^{\star}$ & 2,308 & ,008 & 13,75 & $-1,57$ \\
\hline outside country & & Stage 1: factor driven & 1,50522 & 2,054 & ,884 & $-3,91$ & 6,92 \\
\hline & Stage 3: innovation & Stage 2: efficiency driven & 2,58090 & 1,751 & ,459 & $-2,04$ & 7,20 \\
\hline & & $\begin{array}{l}\text { Stage 4: efficiency driven } \\
\text { (transition countries) }\end{array}$ & $-5,08247$ & 2,323 & ,138 & 11,21 & 1,04 \\
\hline & & Stage 1: factor driven & 6,58769 & 2,546 & 057 &,- 13 & 13,30 \\
\hline & driven (transition & Stage 2: efficiency driven & $7,66337^{\star}$ & 2,308 & ,008 & 1,57 & 13,75 \\
\hline & countries) & $\begin{array}{l}\text { Stage 3: innovation } \\
\text { driven }\end{array}$ & 5,08247 & 2,323 & ,138 & $-1,04$ & 11,21 \\
\hline & & Stage 2: efficiency driven &,- 19988 & $\begin{array}{r}1,6737 \\
1\end{array}$ & ,999 & $-4,61$ & 4,21 \\
\hline & $\begin{array}{l}\text { Stage 1: factor } \\
\text { driven }\end{array}$ & $\begin{array}{l}\text { Stage } 3: \quad \text { innovation } \\
\text { driven }\end{array}$ & $-2,44814$ & $\begin{array}{r}1,6873 \\
9\end{array}$ & ,473 & $-6,90$ & 2,00 \\
\hline & & $\begin{array}{l}\text { Stage 4: efficiency driven } \\
\text { (transition countries) }\end{array}$ & $-4,10022$ & $\begin{array}{r}2,0916 \\
2\end{array}$ & ,214 & $-9,61$ & 1,41 \\
\hline & & Stage 1: factor driven & , 19988 & $\begin{array}{r}1,6737 \\
1\end{array}$ & ,999 & $-4,21$ & 4,61 \\
\hline & $\begin{array}{l}\text { Stage 2: efficiency } \\
\text { driven }\end{array}$ & $\begin{array}{l}\text { Stage } 3: \quad \text { innovation } \\
\text { driven }\end{array}$ & $-2,24826$ & $\begin{array}{r}1,4384 \\
5\end{array}$ & ,407 & $-6,04$ & 1,54 \\
\hline $\begin{array}{l}\% \text { within ANY: } \\
\text { Export: } \quad 75-\end{array}$ & & $\begin{array}{l}\text { Stage 4: efficiency driven } \\
\text { (transition countries) }\end{array}$ & $-3,90034$ & $\begin{array}{r}1,8965 \\
0\end{array}$ & ,179 & $-8,90$ & 1,10 \\
\hline $\begin{array}{l}\text { customers } \\
\text { outside country }\end{array}$ & & Stage 1: factor driven & 2,44814 & $\begin{array}{r}1,6873 \\
9\end{array}$ & ,473 & $-2,00$ & 6,90 \\
\hline & $\begin{array}{l}\text { Stage 3: innovation } \\
\text { driven }\end{array}$ & Stage 2: efficiency driven & 2,24826 & $\begin{array}{r}1,4384 \\
5\end{array}$ & ,407 & $-1,54$ & 6,04 \\
\hline & & $\begin{array}{l}\text { Stage 4: efficiency driven } \\
\text { (transition countries) }\end{array}$ & $-1,65208$ & $\begin{array}{r}1,9085 \\
9\end{array}$ & ,822 & $-6,68$ & 3,38 \\
\hline & & Stage 1: factor driven & 4,10022 & $\begin{array}{r}2,0916 \\
2\end{array}$ & ,214 & $-1,41$ & 9,61 \\
\hline & $\begin{array}{l}\text { Stage 4: efficiency } \\
\text { driven (transition }\end{array}$ & Stage 2: efficiency driven & 3,90034 & $\begin{array}{r}1,8965 \\
0\end{array}$ & ,179 & $-1,10$ & 8,90 \\
\hline & & $\begin{array}{l}\text { Stage } 3: \quad \text { innovation } \\
\text { driven }\end{array}$ & 1,65208 & $\begin{array}{r}1,9085 \\
9\end{array}$ & ,822 & $-3,38$ & 6,68 \\
\hline
\end{tabular}

*. The mean difference is significant at the 0.05 level. 
Leković B., Marić S.: Internationalization of Entrepreneurial Ventures in Transition...

In the final part of the analysis, all these differences between the groups of countries will be also illustrated by calculating the Mahalanobis distance, by which another indicator of similarities and differences is obtained, for the purpose validation and analysis from a different angle identified in the difference between the observed subsamples.

\section{Table 4}

Distance (Mahalanobis) between the groups of countries in relation to observed variables

\begin{tabular}{|c|c|c|c|c|}
\hline & $\begin{array}{l}\text { Factor driven } \\
\text { economies } \\
\text { (1) }\end{array}$ & $\begin{array}{c}\text { Efficiency } \\
\text { driven } \\
\text { other economies } \\
\text { (2) }\end{array}$ & $\begin{array}{l}\text { Innovation } \\
\text { driven } \\
\text { economies } \\
\text { (3) }\end{array}$ & $\begin{array}{c}\text { Efficiency driven } \\
\text { transitional } \\
\text { economies } \\
\text { (4) }\end{array}$ \\
\hline Factor driven economies & .000 & 2,121 & 1,775 & 0.689 \\
\hline Efficiency driven other economies & 2,121 & .000 & 0,346 & 1,432 \\
\hline Innovation driven economies & 1,775 & 0,346 & .000 & 1.086 \\
\hline Efficiency driven transitional econs & 0.689 & 1,432 & 1.086 & .000 \\
\hline
\end{tabular}

Source: Autors' Calculation

Looking at the observed a group of countries from the point of business internationalization at the level of total entrepreneurial activity (anybus) observed a group of countries, the distances in this table point to the fact that the least distance is between efficiency-driven other economies and innovation-driven $(0,346)$. Efficiency-driven other economies and factor-driven economies are the farthest groups of economies (2.121). Since the distance of all major subsamples presents distance from driven efficiency transitional economies compared to other groups of countries, which according to Mahalanobis calculation is in the range of 0.689 to 1.432 , justifies the separation and analysis of the group of transition countries of Central and Eastern Europe, according to the observed variables since are largely manifested specifics that make them different research areas.

\section{Conclusion}

Entrepreneurial behavior and activities, in contemporary economic circumstances at the global level, are identified as a significant potential and valuable resource in creating economic growth, development and the total social prosperity. Only recognizing the phenomenon, entrepreneurship and its glorification will not leave a deep trail and significant effects for economy and society. On the contrary, it will have the same destiny, uncertain result, as any other innovation that is the result of natural activities of an individual or the group. 
Leković B., Marić S.: Internationalization of Entrepreneurial Ventures in Transition...

With all the analyzed groups of countries, as well as with separated group of transitional countries within the framework of efficiency-driven economies, some specifies to all observed characteristics are identified.

Seting the conceptual framework that is focused on the analysis of the total volume of business internationalization of entrepreneurial activities of various degrees with separate transition countries, justify the efforts made. Identified differences between groups of countries on the level of statistical significance, with the confirmed specifics of transition countries in relation to the phenomena under examination is the basic result of the research.

The research results in this paper can be represented by the following conclusions:

- by using MANOVA analysis we confirmed the hypothesis $\mathrm{H} 1$ and concluded that there is a statistically significant difference between the examined groups of countries. Since all countries are grouped as a specific stage of economic development, the group of transition countries stand out as a distinct economic space;

- By using discriminant analysis the hypothesis $\mathrm{H} 2$ we concluded that there are clearly defined borders between compared groups of countries. Thus, the observed groups of countries are separate entities;

- In the ANOVA analysis hypothesis $\mathrm{H}_{3}$ is accepted. It means that there is a significant difference between the groups of countries in relation to all observed characteristics. Also in the analysis of the characteristics of each group and the degree of homogeneity, we conclude that the observed characteristics contribute significantly to the characteristics of the group and that each group exhibits a high level of homogeneity as confirmed by the analysis of Mahalanobis Distance between the groups of countries in relation to observed variables.

All the applied statistical procedures point to the previous assertion, by means of which we obtained the presented results with significant differences, precise limits of separation, characteristics and homogeneity of the groups of countries, as well as their mutual distances. It contributed to all observed characteristics at the level of economic development (as criterion) and the scope of entrepreneurial ventures in internationalization activities.

Based on the information stated previously, we can say that there is solid evidence that small companies are directly involved in international business with a tendency to rise, to a separate group of transition countries and justify the special place within the area of research, since it can absolutely be said that the level of economic development of the country (groups of countries) is an important factor in the process of internationalization. 
Leković B., Marić S.: Internationalization of Entrepreneurial Ventures in Transition...

\section{References}

Axinn, C.N., \& Matthyssens, P. (2002). Limits of internationalization theories in an unlimited world. International marketing review, 19(5), 436-449.

Gjellerup, P. (2000). SME support services in the face of globalisation, concerted action seminar, Opening address. In: Conference Proceedings, Danish Agency for Trade and Industry, Copenhagen. 16-28.

Meyer, K.E. (2001). Institutions, transaction costs, and entry mode choice in Eastern Europe. Journal of international business studies, 32(2), 357-367.

Jansson, H. (2007). International business marketing in emerging country markets: The third wave of internationalization of firms. Edward Elgar Publishing.

Ruzzier, M., Hisrich, R.D., \& Antoncic, B. (2006). SME internationalization research: Past, present, and future. Journal of small business and enterprise development, 13(4), 476-497.

Jansson, H., Johanson, M., \& Ramström, J. (2007). Institutions and business networks: A comparative analysis of the Chinese, Russian, and West European markets. Industrial Marketing Management, 36(7), 955-967.

Söderman, S., Jakobsson, A., \& Soler, L. (2008). A quest for repositioning: The emerging internationalization of Chinese companies. Asian Business \& Management, 7(1), 115-142.

Child, J., \& Rodrigues, S.B. (2005). The Internationalization of Chinese Firms: A Case for Theoretical Extension?. Management and organization review, 1(3), 381-410.

Meyer, K.E., \& Gelbuda, M. (2006). Process perspectives in international business research in CEE. Management International Review, 46(2), 143-164. doi:10.1007/s11575-006-0042-5

Salmi, A. (2000). Entry into turbulent business networks-The case of a Western company on the Estonian market. European Journal of Marketing, 34(11/12), 1374-1390.

Peng, M.W., \& Meyer, K. (2011). International business. London: Cengage Learning.

Cavusgil, S.T., Ghauri, P.N., \& Agarwal, M.R. (2002). Doing business in emerging markets: Entry and negotiation strategies. Sage.

Ghauri, P.N., \& Holstius, K. (1996). The role of matching in the foreign market entry process in the Baltic States. European Journal of Marketing, 30(2), 75-88.

Harvie, C., Lee, B.C., \& Eds., (2005). Sustaining growth and performance in East Asia: The role of small and medium sized enterprises. In . Edward Elgar Publishing. Vol. 3.

-European Commission, (2010). Internationalization of European SMEs. Final Report. Brussels: European Union - Entrepreneurship Unit.

Eriksson, K., Majkgård, A., \& Sharma, D.D. (2000). Path dependence and knowledge development in the internationalization process. MIR: Management International Review, 307-328.

Johnson, S., \& Loveman, G. (1995). Starting Over After Communism: Entrepreneurship and Economic Renewal. Cambridge: Harvard Business School Press.

Bartlett, W., \& Bukvič, V. (2001). Barriers to SME growth in Slovenia. MOCT-MOST: Economic Policy in Transitional Economies, 11(2), 177-195. doi:10.1023/A:1012206414785 
Leković B., Marić S.: Internationalization of Entrepreneurial Ventures in Transition...

Hashi, I. (2001). Financial and institutional barriers to SME growth in Albania: Results of an enterprise survey. MOCT-MOST: Economic Policy in Transitional Economies, 11(3), 221-238. doi:10.1023/A:1013157127524

Muent, H., Pissarides, F., \& Sanfey, P. (2001). Taxes, competition and finance for Albanian enterprises: Evidence from a field study. MOCT-MOST: Economic Policy in Transitional Economies, 11(3), 239-251. doi:10.1023/A:1013161211594

Pissarides, F., Singer, M., \& Svejnar, J. (2000). Objectives and constraints of entrepreneurs: Evidence from small and medium-sized enterprises in Russia and Bulgaria. European Bank for Reconstruction and Development.

Roberts, K., \& Tholen, J. (1998). Young Entrepreneurs in East-Central Europe and the Former Soviet Union. IDS Bulletin, 29(3), 59-64.

Smallbone, D., Welter, F., Voytovich, A., \& Egorov, I. (2010). Government and entrepreneurship in transition economies: The case of small firms in business services in Ukraine. The Service Industries Journal, 30(5), 655-670.

Manolova, T.S., Eunni, R.V., \& Gyoshev, B.S. (2008). Institutional environments for entrepreneurship: Evidence from emerging economies in Eastern Europe. Entrepreneurship Theory and Practice, 32(1), 203-218.

Peng, M.W. (2003). Institutional transitions and strategic choices. Academy of management review, 28(2), 275-296.

Shane, S.A. (2003). A general theory of entrepreneurship: The individual-opportunity nexus. Edward Elgar Publishing. 